\title{
Evaluating Breast Cancer Risk under Exposure to Environmental Estrogen-Like Chemicals
}

\author{
Yuanfang He, Xiaoling Wang, Kusheng Wu* \\ Department of Preventive Medicine, Shantou University Medical College, \\ Shantou 515041, Guangdong, China
}

Received: 8 June 2016

Accepted: 18 July 2016

\begin{abstract}
Breast cancer is the most prevalent cancer among women in the world, with a notable increasing prevalence in recent decades. Many environmental compounds with estrogenic activity, called environmental estrogens (EEs), which are especially persistent organic pollutants, may play important roles in the occurrence and development of breast cancer and even treatment and prognosis. EE compounds, including bisphenol A, nonylphenol, phthalates, perfluorooctane sulfonate, polybrominated diphenyl ethers, dioxins, and polychlorinated biphenyls, result from industrial manufacturing and exist ubiquitously in the human environment. With the aggravation of environmental pollution, these compounds are residual in all kinds of environmental matrices - especially in industrialized countries. Humans are frequently exposed to them through various pathways, including body contact, inhalation, diet, household products, dust, and cosmetics. They have been detected in many types of human specimens. Their persistence in environmental matrices and humans has aroused global attention because of their effect on public health, especially the occurrence of breast cancer. In this review, we focus on recent research of these seven familiar EEs in industrial pollutants to provide insight into the evidence for risk of breast cancer with exposure to environmental estrogen-like chemicals and to provide clues for prevention and control of breast cancer.
\end{abstract}

Keywords: breast cancer, endocrine disruptors, environmental estrogens, bisphenol A, nonylphenol, phthalates, perfluorooctane sulfonate, polybrominated diphenyl ethers, polychlorinated biphenyls, dioxins

\section{Introduction}

Breast cancer is the most serious and common cancer in women worldwide. According to the American Cancer Society, the number of new cases and deaths from breast cancer is still the highest for malignant tumors in the United States in recent years [1]. WHO reported in 2012 that breast cancer accounted for $23 \%$ of all cancer deaths for women. One in every three women in Asia faces life-

*e-mail: kswu@stu.edu.cn long breast cancer risk [2]. Rates for new cases of female breast cancer in China are lower than in Europe, but have increased in recent years with an incidence rate of 13.95 per 100,000 in 2012 [3].

Numerous risk factors identified for breast cancer include the functional loss of breast cancer susceptibility genes, such as BRCA1 and BRCA2 [4], and such lifestyle factors as smoking, alcohol consumption, radiation exposure, and diet. However, the underlying causes of the increasing incidence of breast cancer are indistinct and need to be explored. Hormone-dependent breast cancer is 


\begin{tabular}{|c|c|c|c|c|c|c|c|c|c|c|c|c|c|c|c|c|c|c|c|}
\hline 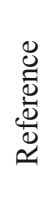 & 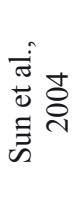 & 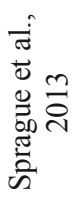 & 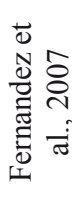 & 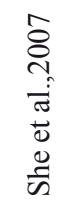 & 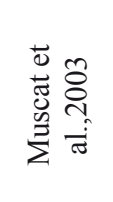 & 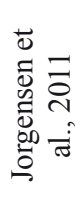 & 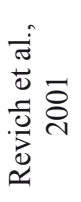 & 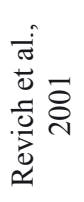 & 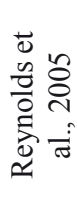 & 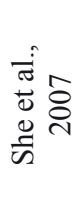 & 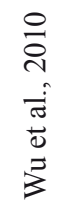 & 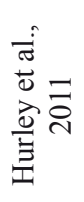 & 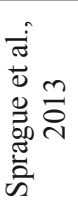 & 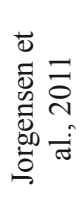 & 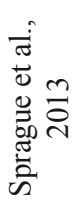 & \multicolumn{4}{|c|}{ 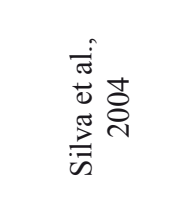 } \\
\hline 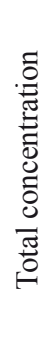 & 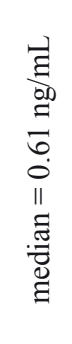 & 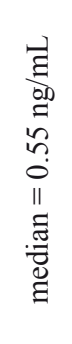 & 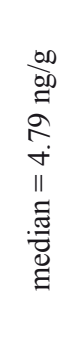 & 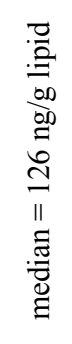 & 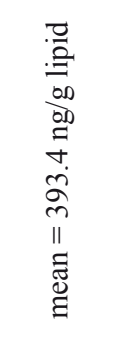 & 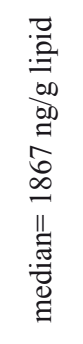 & 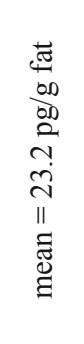 & 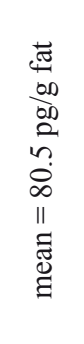 & 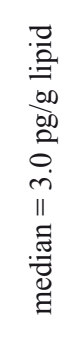 & 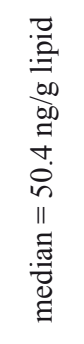 & 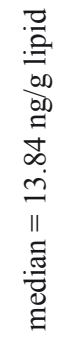 & 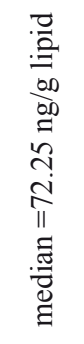 & 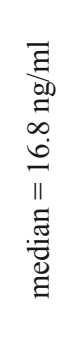 & 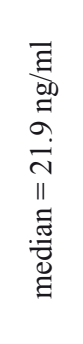 & 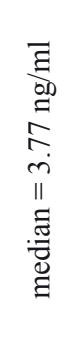 & 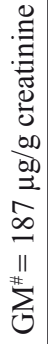 & $\begin{array}{l}0 \\
\infty \\
\infty \\
N \\
\| \\
\sum \\
0\end{array}$ & $\begin{array}{c}n \\
\stackrel{n}{n} \\
\sum_{0}^{\prime \prime}\end{array}$ & $\begin{array}{l}\infty \\
m \\
\infty \\
\sum_{0}\end{array}$ \\
\hline 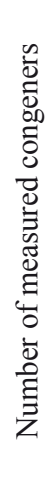 & & & & 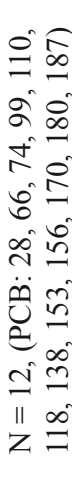 & 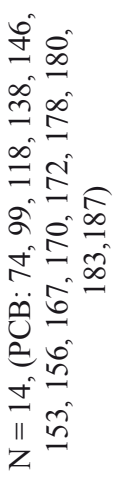 & 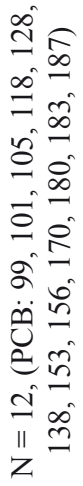 & 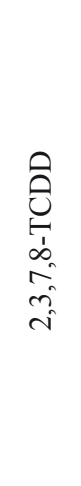 & 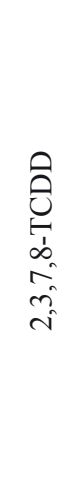 & 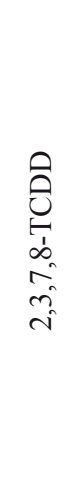 & 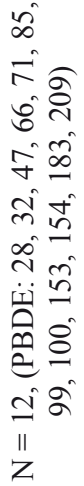 & 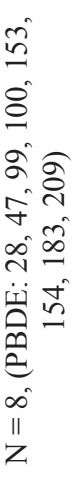 & 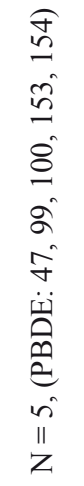 & & & 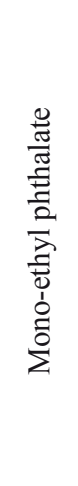 & 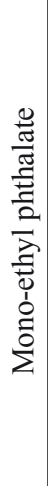 & 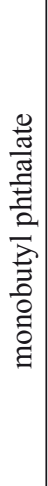 & 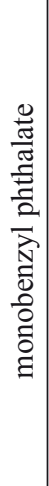 & 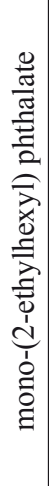 \\
\hline
\end{tabular}

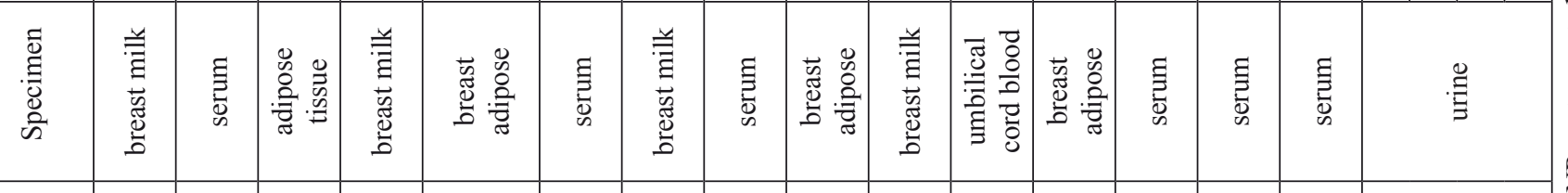

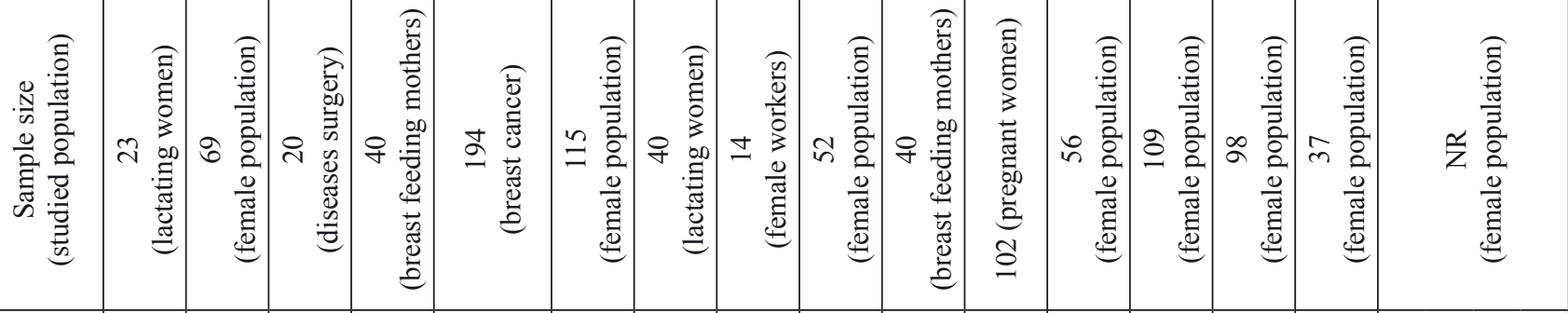

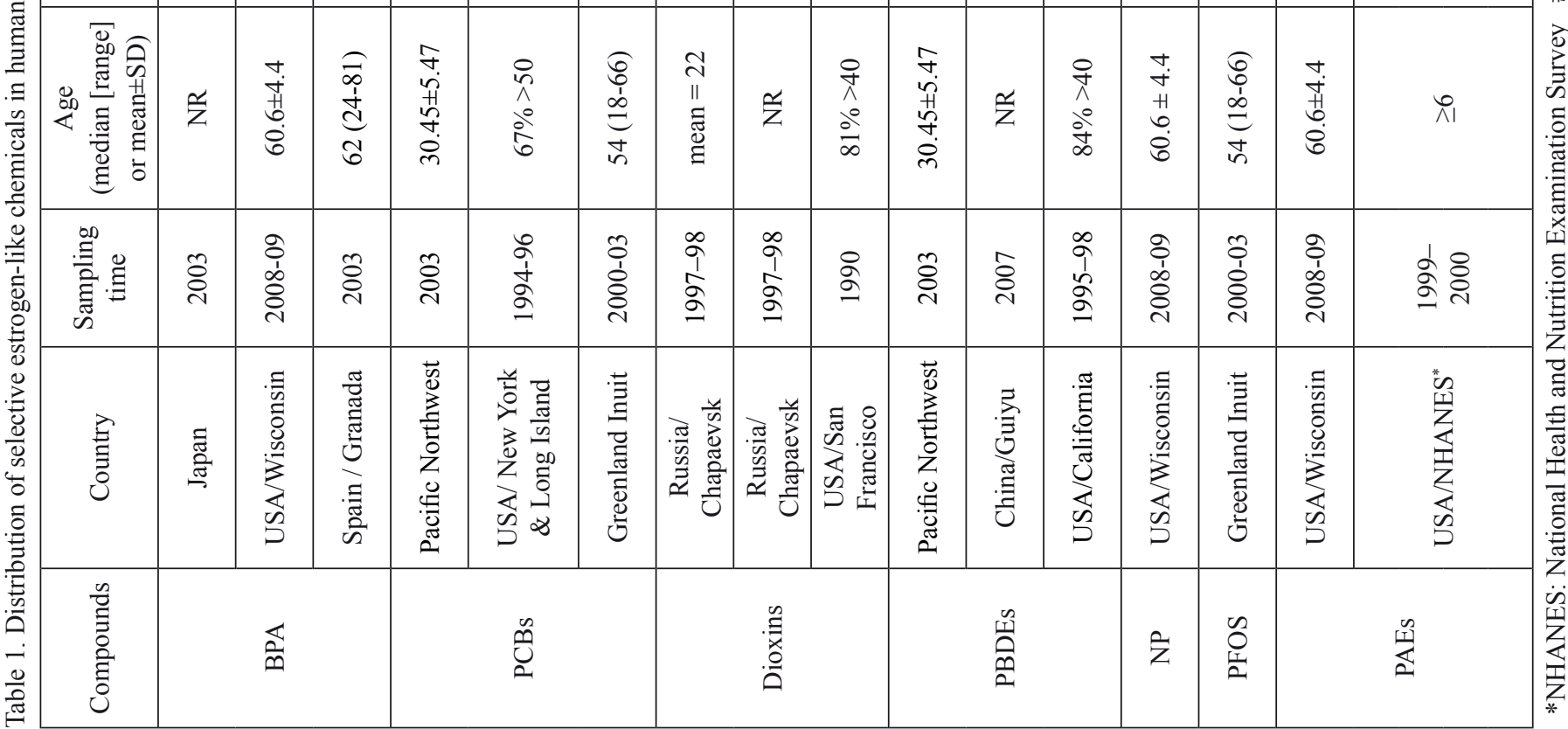


related to exposure to high estrogen levels. Estrogen levels in the body can be altered with early-onset menarche, late menopause, nullipara, the late age of a first pregnancy, not breastfeeding, and exposure to pharmacological estrogens by use of the contraceptive pill and hormone replacement therapy. All of these events have been reported to be risk factors for breast cancer development and growth [5-6].

The exogenous environmental compounds with estrogenic activity are classified as environmental estrogens (EEs). EEs can bind to estrogen receptors and imitate endogenous estrogens exerting estrogen-like effects and interfere with the regulation of the growth and the proliferation of mammary glands by endogenous estrogens. Therefore, EEs are suspected of playing an important role in the occurrence and development of breast cancer and even treatment and prognosis. Exposure to environmental estrogen-like chemicals could affect pubertal timing. Indeed, a cohort study of puberty in girls revealed a delay in puberty onset with increased persistent organic pollutant concentrations [7]. With the acceleration of industrial pollution, persistent organic pollutants continuously released into the environment include dioxins, phthalates, bisphenol A, nonylphenol, perfluorooctane sulfonate, polychlorinated biphenyls, and polybrominated diphenyl ethers. These environmental estrogen-like chemicals not only are enriched in environmental matrices but also bio-accumulate in human tissues. The distribution and concentration of these seven environmental estrogen-like chemicals in human specimens are presented in Table 1. Although evidence from environmental and experimental research has shown that EEs can bind to estrogen receptors (ER) or aryl hydrocarbon receptors (AhR), inducing estrogen activities and affecting intrastitial estrogen levels and thereby affecting reproductive development and reproductive system diseases [8-9], there is no clear mechanism for explaining the relationship between EEs and breast cancer occurrence and development. The impact of EEs on human health and particularly breast cancer remains to be determined, especially the impact of EEs that are measurable in human specimens, including blood, breast milk, breast tissue, urine, and other tissues.

This review aimed to examine the evidence for the contribution of the seven EEs in industrial pollutants to the occurrence and development of breast cancer or to the prognosis and survival of breast cancer affected by EE exposure during the progress of breast cancer therapy. We focus on these seven EEs to give an overall insight into the risk of breast cancer with exposure to the compounds and to provide clues for further studies on EEs and breast cancer risk.

\section{Bisphenol A (BPA)}

BPA is polymerized to manufacture polycarbonate plastic and epoxy resin and is used to make baby formula and water bottles, water pipes, dental sealants, coatings on the inside of almost all food and beverage cans, toys, athletic safety equipment, medical equipment and tubing, consumer electronics, and eyeglass lenses. It is also an additive for thermal papers, flame-retardants, and brake fluids. BPA can leach into food and beverages, which is the main exposure route for humans. BPA is lipophilic and has been detected in human breast milk, breast adipose tissue, urine, and serum [10-12]. BPA can also be detected in maternal and fetal serum, placental tissue, and amniotic fluid [13-14].

The structure of BPA is similar to that of estradiol and it has estrogenic properties [15]. BPA is considered to play a part in the development of breast cancer, and BPA exposure might increase the risk of breast cancer. Fernandez and Russo reported that BPA could cause neoplastic transformation in human breast epithelial cells [16]. BPA can increase the expression of estrogen receptors and the number of terminal end buds altering the development of mammary glands [17], so it may predispose the mammary gland to carcinogenesis. Pubertal exposure to low-dose BPA increased lateral branches and hyperplasia in adult Balb/c mouse mammary glands; it acutely increased mammary stem cell (MaSC) in 6-week-old glands and delayed the increase in luminal progenitors in 4-month-old adult glands [18]. BPA altered the function of MaSCs from different age groups, causing early neoplastic lesions in regenerated glands, so MaSCs are susceptible to BPA-induced transformation. This study suggests for the first time that pubertal BPA exposure altered MaSC gene expression and function to induce early neoplastic transformation. Other studies have indicated that prenatal exposure to BPA increased mammographic density - yet another risk factor for human breast cancer [19]. In considering the interaction of gene mutations and BPA exposure, Fernandez et al. showed that in breast cancer tissue with BRCAl or $B R C A 2$ mutations, MCF-10F cells (normal-like human breast epithelial cells) were susceptible to transformation by BPA [20]. Interaction of those environmental and genetic factors might augment the risk of tumorigenesis of the breast. Several environmental factors might increase the risk of tumorigenesis in BRCA1-defective breast epithelial cells [21]. The homeobox-containing gene HOXC6 is associated with mammary gland development and is overexpressed in various cancers, including breast and prostate. Hussain et al. found that BPA induced the expression of HOXC6 in breast cancer tissue in vitro and in vivo [22]. In investigating the transcriptional regulation of HOXC6 via estradiol (E2) and BPA, the authors found that the estrogen receptor $\alpha(\mathrm{ER} \alpha)$ and ER-coregulators such as MLL-histone methylases bound to the HOXC6 promoter on exposure to BPA, which increased histone H3K4-trimethylation, histone acetylation, and recruitment of RNA polymerase II at the HOXC6 promoter [22]. HOXC6 overexpression induced the expression of tumor growth factors and facilitated 3D colony growth formation, which indicates its potential roles in tumor growth. Animal experiments also showed the potential effect of BPA on breast cancer with prenatal exposure, 
which disturbed the development of mammary glands and increased carcinogenic susceptibility [23].

Few epidemiological studies have linked BPA to breast cancer. According to the U.S. Institute of Medicine, the available evidence was insufficient to draw a firm conclusion of the relation of BPA exposure and breast cancer [24]. Yang and coworkers did not find a significant difference in blood BPA levels between breast cancer patients and controls [25]. The major BPA metabolite (BPA-glucuronide) was measured in urine but had no association with postmenopausal breast cancer [26]. However, Sprague et al. found increased serum BPA levels associated with increased mammographic breast density [27]. The inconsistency may be due to sampling methods and sample size as well as studies conducted in different countries.

Although evidence from epidemiological studies for a direct relationship between BPA and breast cancer is lacking, the risks cannot be ignored. For breast cancer therapy, BPA at low nanomolar doses (i.e., environmentally relevant doses) can oppose the action of chemotherapeutic agents to reduce their efficacy [28]. BPA was also significantly associated with breast tumors, characterized by high histologic grade and large tumor size, for decreased recurrence-free patient survival [29]. Thus, exposing breast cancer patients to EPA should be considered when choosing therapeutic regimens.

The hazards of BPA cannot be ignored in the whole process of breast cancer, including neoplastic transformation, development, and even therapy. Currently, most of the evidence is based on animal studies; further research of larger samples and well-designed biomonitoring studies are needed to confirm the phenomena observed in the cell lines and animal experiments, which would be valuable for breast cancer prevention and treatment.

\section{Nonylphenol (NP)}

NP is applied to synthesize nonylphenol ethoxylates, which are nonionic surfactants used as emulgators, lubricant additives, antioxidants, or stabilizers in industrial, agricultural, and domestic consumer products. NP can leach into the environment during both the manufacturing process and from final products. The extensive use of NP has resulted in its ubiquitous exposure to humans. Both in vitro and in vivo studies showed that NP plays a role in the occurrence of breast cancer. NP can mimic estrogen and act as an agonist for estrogen receptors in MCF-7 breast cancer cells (human breast cancer cell line) [30]. NP was found to trigger DNA mutations and chromosomal abnormalities in in vitro experiments [31] and induce cell proliferation in MCF-7 cells [32]. In another study, MCF-7 cells exposed to NP showed increased expression of cyclin D1 and cathepsin D and decreased $p 21$ expression at both transcriptional and translational levels; however, NPinduced alterations of these genes were blocked by ICI 182 and 780 , so changes in expression of these genes may be regulated by an ER $\alpha$-dependent pathway [33]. Therefore, NP may induce cell cycle-related gene expression to increase MCF-7 cell proliferation and intensively activate cathepsin $\mathrm{D}$ to promote cancer metastasis. In addition, NP may be involved in signal transduction to inhibit apoptosis induced by estrogen deletion in T47D breast cancer cells [34]. The offspring of rats treated with NP during pregnancy showed changed mammary gland development [35].

NP can also activate pregnane-X receptors (PXR) and induce P-450 enzymes, which are responsible for producing $\mathrm{E}_{3}$, an estrogen receptor agonist, to increase the risk of breast cancer [36]. The authors suggest that NP might increase breast cancer risk by increasing $\mathrm{E}_{3}$ production. MMTVneu mice treated with NP for 32 weeks showed an increased incidence of mammary cancer [37].

Epidemiological studies of the association of NP and breast cancer are scarce, and further studies with human specimens are needed.

\section{Phthalates (PAEs)}

PAEs are a family of compounds made from alcohols and phthalic anhydride, which can prolong the lifespan or durability of plastics and increase the flexibility of some plastics. They are widely used in our daily life, especially for medication; personal care products, including cosmetics, perfume, hair spray, and shampoo; detergent; adhesives; and even foods and food preservatives. PAEs are commonly found in foods and house dust, with food being the primary source of human exposure. Because the general population is commonly and continually exposed to PAEs, the health effects of PAEs have garnered increasing concern [38]. PAEs tend not to bioaccumulate in the body. Urinary concentrations of phthalate metabolites have been used extensively to assess exposure to PAEs in epidemiologic studies [39]. The detrimental impacts of PAEs have been reported, and the association with breast cancer has been evaluated in some studies. Exposure to the parent compound of the phthalate metabolite mono-(2ethylhexyl) phthalate (MEHP) was found to be associated with breast cancer on both univariate analysis (odds ratio (OR) 2.16, 95\% CI 1.16-4.05, $\mathrm{p}=0.02$ ) and multivariable analysis (OR 2.43, 95\% CI 1.13-5.25, p = 0.02) [40]. López-Carrillo et al. evaluated the risk of breast cancer with PAE exposure by urinary concentrations of several phthalate metabolites in northern Mexican women (agematched 233 cases to 221 controls): the concentration of MEP, the main metabolite of diethyl phthalate (DEP), was higher in cases than controls and positively associated with breast cancer incidence $\left(\mathrm{OR}_{\text {highest vs. lowest tertile }} 2.20\right.$, 95\% CI 1.33-3.63) and the association was stronger for premenopausal women $\left(\mathrm{OR}_{\text {highest vs. lowest tertile }} 4.13,95 \% \mathrm{CI}\right.$ 1.60-10.70) [41].

Carran and Shaw reported a greater incidence of breast cancer in children of New Zealand Malayan war veterans who had been exposed to dibutyl phthalate (DBP) than the general population ( $4 \%$ vs. $0.48 \%)$. The 
possible mechanism may be that phthalates and/or their metabolites induce DNA damage and affect heredity, thereby increasing the cancer risk for offspring [42].

Because the half-lives of PAEs are relatively short, avoidance of daily exposure would be beneficial for preventing breast cancer. Changing lifestyles, especially reducing the use of personal care products with added PAEs, can decrease the PAE exposure opportunity, which might also reduce the risk of breast cancer [43].

\section{Perfluorooctane Sulfonate (PFOS)}

Perfluorooctanesulfonyl fluoride is a synthetic perfluorinated compound with a sulfonyl fluoride functional group that is used in a wide variety of consumer products such as carpets, upholstery, and textiles. These compounds degrade to PFOS, a final degradation product, which is a persistent metabolite that accumulates in tissues of humans and wildlife [44]. PFOS are widespread in the environment and exist in the tissues of fish, birds, and marine mammals. It is an emerging persistent organic compound with a long half-life. PFOS can bioaccumulate to high trophic levels of the food chain, which implies a high exposure to humans [45]. The observed serum and plasma concentrations of PFOS range from 1 to $116 \mathrm{ng} / \mathrm{ml}$ [44].

As for other persistent organic pollutants, PFOS also possess estrogen-like properties [46]. PFOS can enhance the effects of $17 \beta$-estradiol (E2) on estrogen-responsive gene expression, extracellular signal-regulated kinase $1 / 2$ (ERK1/2) activation, and growth of hormone-deprived T47D human breast cancer cells [47]. The effects of PFOS on human breast cancer have raised concerns in recent years. A case-control study of 31 cases and 115 controls of Greenlandic Inuit found that the median serum level of PFOS in breast cancer patients was twofold that of controls. Whether before or after adjustment for the corresponding confounders, including age, BMI, pregnancy, cotinine, breastfeeding, and menopausal status, breast cancer risk was related to serum concentrations of PFOS (adjusted OR 1.03, 95\% CI 1.001-1.07) [44]. In a subsequent study, the authors found increased risk of breast cancer in Inuit women with BRCA1 founder mutation and polymorphisms in CYP1A1 (Val) and CYP17 (A1) and the risk increased with increased serum levels of PFOS [48].

Grice et al. used a questionnaire-based study of workers exposed to perfluorooctanesulfonyl fluoride and found no association of PFOS exposure and several cancers, including breast cancer [49]. However, the authors did not collect serum or tissue samples to evaluate PFOS levels in women workers, and the exact body levels of PFOS were unknown.

Data on this compound are scarce and findings are inconsistent, with limitations in the literature, so confirmed conclusions are seldom reached. Research with large-scale, prospective controlled cohort designs would be useful for evaluating the links between PFOS exposure and breast cancer.

\section{Polybrominated Diphenyl Ethers (PBDEs)}

PBDEs are flame retardants used extensively in such consumer products as electronics, fabrics, and polyurethane foam. Because PBDEs are additives, they can be released from products and furnishings and can be found in outdoor air, sediments, sludge, and soil, as well as house and office air and dust. Like other persistent organic pollutants, PBDEs have been detected in such wildlife as birds, marine species, fish, and terrestrial animals; and in humans, including in blood, serum, adipose tissue, and breast milk [50]. PBDEs ingested by inhalation, dermal absorption and food intake accumulate in the body. In Shenzhen, China, the main route of PBDE exposure for adults is food [51]. However, some research shows the key routes as being household consumer products [52].

Because of the estrogen-like effects of PBDEs [53], the risk of breast cancer may be increased with PBDE exposure. In addition, considering the carcinogenicity of PBDEs, the chemical structure and toxicological properties are similar to known carcinogens such as polychlorinated biphenyls and other dioxin-like compounds [54]; therefore, the association of PBDEs and breast cancer seems reasonable. PBDE-209 promoted the proliferation of various cancer cells from the female reproductive system and normal ovarian Chinese hamster ovary (CHO) cells. Furthermore, it reduced tamoxifen-, protein kinase $\mathrm{C} \alpha(\mathrm{PKC} \alpha)$-, and ERK-inhibited apoptosis and upregulated phosphorylation of PKC $\alpha$ and ERK1/2 proteins in tumor cells and $\mathrm{CHO}$ cells [55]. In a casecontrol study of breast cancer and exposure to synthetic environmental chemicals in native Alaskan women, BDE47 levels were significantly higher in cases than controls (geometric mean 38.8 vs. $25.1 \mathrm{ng} / \mathrm{g}$ lipid; $\mathrm{p}=0.04$ ) [40]. However, the authors also indicated that this study was limited by a small sample size and an inability to control for the confounding effects of BMI, so the association between BDE-47 and breast cancer warrants further investigation. Another case-control study tried to examine the relationship of the body burden of PBDEs and the risk of breast cancer. The results were negative, with no evidence of a link between PBDE adipose concentrations measured at or near the time of diagnosis and breast cancer risk [56]. However, the controls included women with other proliferative benign breast lesions, suggested to be a risk factor of breast cancer. The small sample size (78 cases and 56 controls) was another limitation. Further studies with a prospective design and more representative controls would help reveal the true effect of PBDEs on breast cancer. In addition, PBDE levels were found inversely related to age, so the body burden of PBDEs measured at or near the time of diagnosis cannot reveal the real damage for breast cancer [57].

McElroy and colleagues [58] evaluated recent consumption of Great Lakes fish exposed to organic pollutants, including PBDEs. Recent consumption of sportcaught fish was not associated with risk of breast cancer in postmenopausal women but was associated with the risk in premenopausal women (relative risk (RR) 1.70, 95\% CI 
1.16-2.50) [58]. Whether the result occurred by chance or not, more studies with parallel results will help to ensure whether the contamination of PBDEs in the environment and food is associated with the development of breast cancer, especially in young and premenopausal women.

\section{Dioxins}

Dioxins are universal persistent organic pollutants with reproductive toxicity existing in the environment. In general, dioxins are by-products from cement and metal manufacturing industries when chlorinated substances are burned incompletely, and from some chemical production process such as the manufacture of herbicides, insecticides, and defoliants. Dioxins also are generated by such daily activities as garbage incineration [59-60]. They can gather in tiny particles in the atmosphere, soil, and water. Because they are highly lipophilic and degradationresistant, dioxins can bio-accumulate in the food chain and be enriched by adipose tissues. Therefore, humans can be exposed through environmental contact or ingestion of contaminated air, dust, oil, food, and drinking water [61$62]$. In the general population, diet is considered one of the main sources of exposure to dioxins. Dioxins have been found frequently in adipose tissue, blood, and milk of the human body [62-63].

Dioxins are a family of organochlorine compounds with 210 structurally similar congeners, comprising 75 polychlorinated dibenzo-p-dioxin (PCDDs) isomers and 135 polychlorinated dibenzofuran (PCDFs) isomers. The 2,3,7,8-Tetrachlorodibenzo-p-dioxin (TCDD) was studied extensively in previous studies and was used as a reference chemical for dioxins. TCDD was classified as a group 1 carcinogen by the International Agency for Research on Cancer in 1997 [60, 64]. As a carcinogen for humans, dioxins can combine with the aryl hydrocarbon receptor (AhR) to activate and induce the AhR pathway mediating cytochrome P450 (CYP1) expression, disrupting endocrine functions and thereby leading to adductive and oxidative DNA damage and resulting in mutagenesis as an incentive for diseases [65-66]. Some studies showed that dioxins played a protective role in breast cancer development because TCDD can induce the expression of CYP1A1 and CYP1B1 to catalyze estradiol (E2) metabolism, leading to reduced E2 levels in breast tissue cells [9, 67-68]. Studies also reported that 6-methyl1,3,8-trichlorodibenzofuran can inhibit E2-induced cell proliferation and tumor growth and prevent E2-increased levels of ER and progesterone receptors (PR) [69-70]. But some studies found that dioxins can elicit AhR-mediated estrogenic activity by interacting with ER and promote gene expression and the proliferation of breast cancer cells [71-72]. In contrast to the above two viewpoints, Spink and his collaborators thought TCDD-induced AhR expression had no relationship with the proliferation and estrogen-stimulated tumor formation of MCF-7 cells [73]. However, dioxin receptor and ER signaling shows crosstalk, and dioxin-activated AhR expressed anti- estrogenic effects depending on estrogen, but estrogenic effects are independent of estrogen [9, 74-75]. Therefore, the mechanism of the relationship between dioxins and breast cancer is still unclear.

In epidemiological studies, two early cohort studies (the Seveso cohort of community residents exposed to dioxins by industrial accident and the Hamburg cohort of workers exposed during the production of herbicides) revealed an increase in breast cancer incidence with increasing serum dioxin exposure [76-77]. Subsequent cohort studies also showed increased incidence and mortality with breast cancer on dioxin exposure. Pesatori et al. studied the cancer incidence of residents of Seveso, Italy, experiencing a chemical pollution accident from 1977 to 1996 and found much higher soil TCDD levels in residents of zone A (nearest to the accident site) as compared with residents in a unpolluted reference territory (RR 2.57, 95\% CI 1.07-6.20) [78]. Manuwald et al. reported that female workers with dioxin exposure during chemical production had increased breast cancer mortality (standardized mortality ratio $1.86,95 \%$ CI 1.12-2.91) [60]. One bit of research combined space and space-time factors with dioxin pollution to explore the relationship with breast cancer, and found there was a significantly spatial association [79]. However, a recent cohort study investigated dietary dioxin uptake level distribution in different groups by demographic characteristics, reproductive/reproductive characteristics, and ER/PR expression. The result showed increasing dioxin intake levels associated with declining breast cancer risk in post-menopausal women with ER-negative/PR-negative tumors [59]. In contrast, epidemiological case-control studies found no apparent association between dioxin exposure and breast cancer [80-81].

Because of various retrospective interference factors in case-control studies, no significant association has been found. Although Danjou et al. [59] reported breast cancer risk negatively associated with dioxin intake in ER-negative/PR-negative post-menopausal women, single food exposure reflected only a part of human dioxin exposure. Because most of the more convincing cohort studies support increased breast cancer risk with dioxin exposure, more extensive studies in vivo and in vitro are needed to explain the relationship between dioxins and breast cancer.

\section{Polychlorinated Biphenyls (PCBs)}

PCBs are used as dielectric fluids in industry to make transformers and capacitors, organic diluents, plasticizers, adhesives, and flame retardants, and have several other industrial applications. They are highly stable and lipophilic chemicals. In the food chain, they can accumulate in human fat tissues, including adipose tissue, plasma lipids, and milk fat [82]. One study supported PCB levels associated with increasing age, fish consumption, and heavy alcohol consumption, but a history of breastfeeding can reduce the risk [83]. 
PCBs have estrogenic properties. Wolff et al. classified PCB congeners by their different structures and properties. Hormonal and non-hormonal activities of PCBs depend on the structure [84]. Potential estrogenic PCBs are usually ortho-substituted, non-planar congeners, and/or their hydroxylated metabolites. Since the early 1990s, PCBs have been considered to play a causal role in the etiology of breast cancer through estrogen-related pathways. Subsequently, many researchers have started to confirm this hypothesis. Literature reviews of PCBs and breast cancer (before 1994) found no increased risk of breast cancer with environmental exposure [85-86]. In the Key and Reeves review [85], from six small epidemiological studies (301 cases, 412 controls), the summary ratio was 1.01 (99\% CI 0.92-1.10) and in the Adami et al. review [86], the rate ratio was 0.84 (95\% CI $0.50-1.33)$.

In early studies, researchers explored the effects of PCB exposure with the sum of all PCB congeners as the measure of exposure and usually found no evidence of increased breast cancer risk with total PCB levels. A review conducted by Golden et al. concluded that the weight of evidence did not support a causal association between human cancer and PCB exposure [87]. From the comprehensive reviews about breast cancer [88-89], the association between PCB exposure and breast cancer may be obscured by the use of different epidemiologic methods (case-control study, nested-control study, cohort study, etc.) and indexes (breast cancer mortality, breast cancer incidence, or both); at the same time, the exposure level of PCBs was evaluated by different body specimens collected before or after diagnosis. In addition, with improved PCB detection and many changeable factors, explaining the inconsistency among studies becomes more complex and sophisticated.

In later studies, researchers explored the association of breast cancer and individual PCB congeners or groups (by their properties) of congeners. The results were often inconsistent. For example, the joint effects of nine PCB congeners were analyzed in one study, with a protective effect on breast cancer risk with PCB 156 exposure reported [90]. In another congener-specific analysis study, the authors observed higher PCB 156 concentrations in women with breast cancer (OR 1.80, 95\% CI 1.11-2.94; fourth vs. first quartile) [91]. Diorio et al. suggested an association between increased plasma levels of some PCB congeners (153, 183, 196, and combined Wolff group $3 \mathrm{PCBs}$ ) and postmenopausal women with lower mammographic density [92].

Studies showed the periods of fetal, peri-pubertal, and pregnancy as susceptible to breast cancer [93]; exposure at these periods would be a risk factor for breast cancer. Cohn and co-researchers found in a nested case-control study that exposure to PCB 203, measured shortly after delivering, was strongly associated with breast cancer incidence before age 50 [94].

The Golden and Kimbrough review concluded no evidence of increased risk of breast cancer and occupational exposure to PCBs [95]. Doubting the sensitivity of mortality, Silver and colleagues evaluated breast cancer incidence in 5,752 women with occupational PCB exposure who worked at least one year in capacitor facilities and found no overall increased incidence of breast cancer. For the subgroup of non-white workers, the exposure-related risk was increased, although limited by a small number of cases. The authors did not collect body samples to evaluate the body burden of PCBs but assessed the $\mathrm{PCB}$ exposure by semiquantitative job-exposure matrices [96]. During exposure to PCBs, many potential confounders and biases, such as the healthy worker effect, may underestimate the PCB association.

\section{Conclusions}

Exposure to EEs is a life-long health risk that only increases later in life. The collaboration of environmental health and oncology would be of crucial significance in the study of environmental estrogens. We live in an environment full of EE pollution, in surface water, sediments, and soils, and in diets, household dust, the community, and work. Except for genetic factors, complex EE pollution may play a role in the increase in breast cancer incidence, and there are windows in a lifetime that are susceptible to environmental exposure.

Avoiding daily exposure would help prevent breast cancer. To prevent the occurrence and development of breast cancer, researchers should assess how food, water, and consumer products contribute to the overall and differential risk among subpopulations, and knowledge and/or advice should be provided. Society should pay attention to the problem and try to protect the environment to make it less carcinogenic. Societal decisions that shape individual behavior and circumstances are needed. Also, people should reduce potential risk by avoiding exposure to EEs.

\section{Acknowledgements}

This work was supported by the National Natural Science Foundation of China (No. 81470152) and the Department of Education, Guangdong Government under the Top-tier University Development Scheme for Research and Control of Infectious Diseases. We thank Ms. Laura Smales for her constructive comments and language editing.

\section{References}

1. SIEGEL R., NAISHADHAM D., JEMAL A. Cancer statistics, 2012. CA Cancer J Clin 62, 10, 2012.

2. DONEPUDI M.S., KONDAPALLI K., AMOS S.J., VENKANTESHAN P. Breast cancer statistics and markers. J Cancer Res Ther 10, 506, 2014.

3. CHEN W., ZHENG R., ZUO T., ZENG H., ZHANG S., HE J. National cancer incidence and mortality in china, 2012. Chin J Cancer Res 28, 1, 2016.

4. MAVADDAT N., REBBECK T.R., LAKHANI S.R., 
EASTON D.F., ANTONIOU A.C. Incorporating tumour pathology information into breast cancer risk prediction algorithms. Breast Cancer Res. 12, R28, 2010.

5. BERNSTEIN L. Epidemiology of endocrine-related risk factors for breast cancer. J Mammary Gland Biol Neoplasia 7, 3, 2002.

6. VELIE E.M., NECHUTA S., OSUCH J.R. Lifetime reproductive and anthropometric risk factors for breast cancer in postmenopausal women. Breast Dis 24, 17, 2005.

7. WINDHAM G.C., PINNEY S.M., VOSS R.W., SJODIN A., BIRO F.M., GREENSPAN L.C., STEWART S., HIATT R.A., KUSHI L.H. Brominated flame retardants and other persistent organohalogenated compounds in relation to timing of puberty in a longitudinal study of girls. Environ. Health Perspect. 123, 1046, 2015.

8. BERNANKE J., KOHLER H.R. The impact of environmental chemicals on wildlife vertebrates. Rev Environ Contam Toxicol 198, 1, 2009.

9. L'HERITIER F., MARQUES M., FAUTEUX M., GAUDREAU L. Defining molecular sensors to assess longterm effects of pesticides on carcinogenesis. Int J Mol Sci 15, 17148, 2014.

10. FERNANDEZ M., ARREBOLA J., TAOUFIKI J., NAVAL N A., BALLESTEROS O., PULGAR R., VILCHEZ J., OLEA N. Bisphenol-a and chlorinated derivatives in adipose tissue of women. Reprod. Toxicol. 24, 259, 2007.

11. HIROI H., TSUTSUMI O., TAKEUCHI T., MOMOEDA M., IKEZUKI Y., OKAMURA A., YOKOTA H., TAKETANI Y. Differences in serum bisphenol a concentrations in premenopausal normal women and women with endometrial hyperplasia. Endocr. J. 51, 595, 2004.

12. SUN Y., IRIE M., KISHIKAWA N., WADA M., KURODA N., NAKASHIMA K. Determination of bisphenol a in human breast milk by hplc with column-switching and fluorescence detection. Biomed. Chromatogr. 18, 501, 2004.

13. SCHÖNFELDER G., WITTFOHT W., HOPP H., TALSNESS C.E., PAUL M., CHAHOUD I. Parent bisphenol a accumulation in the human maternal-fetal-placental unit. Environ. Health Perspect. 110, A703, 2002.

14. YAMADA H., FURUTA I., KATO E.H., KATAOKA S., USUKI Y., KOBASHI G., SATA F., KISHI R., FUJIMOTO S. Maternal serum and amniotic fluid bisphenol a concentrations in the early second trimester. Reprod. Toxicol. 16, 735, 2002

15. VANDENBERG L.N., MAFFINI M.V., SCHAEBERLE C.M., UCCI A.A., SONNENSCHEIN C., RUBIN B.S., SOTO A.M. Perinatal exposure to the xenoestrogen bisphenol-a induces mammary intraductal hyperplasias in adult cd-1 mice. Reprod. Toxicol. 26, 210, 2008.

16. FERNANDEZ S.V., RUSSO J. Estrogen and xenoestrogens in breast cancer. Toxicol Pathol 38, 110, 2010.

17. SOTO A.M., BRISKEN C., SCHAEBERLE C., SONNENSCHEIN C. Does cancer start in the womb? Altered mammary gland development and predisposition to breast cancer due to in utero exposure to endocrine disruptors. J Mammary Gland Biol Neoplasia 18, 199, 2013.

18. WANG D., GAO H., BANDYOPADHYAY A., WU A., YEH I.T., CHEN Y., ZOU Y., HUANG C., WALTER C.A., DONG Q., SUN L.Z. Pubertal bisphenol a exposure alters murine mammary stem cell function leading to early neoplasia in regenerated glands. Cancer Prev Res (Phila) 7, 445, 2014.

19. MAFFINI M.V., RUBIN B.S., SONNENSCHEIN C., SOTO A.M. Endocrine disruptors and reproductive health: The case of bisphenol-A. Mol. Cell. Endocrinol. 254, 179, 2006.

20. FERNANDEZ S.V., HUANG Y., SNIDER K.E., ZHOU Y.,
POGASH T.J., RUSSO J. Expression and DNA methylation changes in human breast epithelial cells after bisphenol a (bpa) exposure. Int. J. Oncol. 41, 369, 2012.

21. KANG H.J., HONG Y.B., YI Y.W., CHO C.H., WANG A., BAE I. Correlations between brca1 defect and environmental factors in the risk of breast cancer. J Toxicol Sci 38, 355, 2013.

22. HUSSAIN I., BHAN A., ANSARI K.I., DEB P., BOBZEAN S.A., PERROTTI L.I., MANDAL S.S. Bisphenol-a induces expression of hoxc6, an estrogen-regulated homeoboxcontaining gene associated with breast cancer. Biochim. Biophys. Acta 1849, 697, 2015.

23. DURANDO M., KASS L., PIVA J., SONNENSCHEIN C., SOTO A.M., LUQUE E.H., MU OZ-DE-TORO M. Prenatal bisphenol a exposure induces preneoplastic lesions in the mammary gland in wistar rats. Environ. Health Perspect. 115, 80, 2007

24. SMITH-BINDMAN R. Environmental causes of breast cancer and radiation from medical imaging: Findings from the institute of medicine report. Arch. Intern. Med. 172, 1023, 2012.

25. YANG M., RYU J.-H., JEON R., KANG D., YOO K.-Y. Effects of bisphenol a on breast cancer and its risk factors. Arch. Toxicol. 83, 281, 2009.

26. TRABERT B., FALK R.T., FIGUEROA J.D., GRAUBARD B.I., GARCIA-CLOSAS M., LISSOWSKA J., PEPLONSKA B., FOX S.D., BRINTON L.A. Urinary bisphenol a-glucuronide and postmenopausal breast cancer in poland. Cancer Causes Control 25, 1587, 2014.

27. SPRAGUE B.L., TRENTHAM-DIETZ A., HEDMAN C.J., WANG J., HEMMING J.D., HAMPTON J.M., BUIST D.S., AIELLO BOWLES E.J., SISNEY G.S., BURNSIDE E.S. Circulating serum xenoestrogens and mammographic breast density. Breast Cancer Res. 15, R45, 2013.

28. LAPENSEE E.W., TUTTLE T.R., FOX S.R., BENJONATHAN N. Bisphenol a at low nanomolar doses confers chemoresistance in estrogen receptor-alpha-positive and -negative breast cancer cells. Environ. Health Perspect. 117, 175,2009

29. DAIRKEE S.H., SEOK J., CHAMPION S., SAYEED A., MINDRINOS M., XIAO W., DAVIS R.W., GOODSON W.H. Bisphenol a induces a profile of tumor aggressiveness in high-risk cells from breast cancer patients. Cancer Res. 68, 2076, 2008.

30. VIVACQUA A., RECCHIA A.G., FASANELLA G., GABRIELE S., CARPINO A., RAGO V., DI GIOIA M.L., LEGGIO A., BONOFIGLIO D., LIGUORI A. The food contaminants bisphenol a and 4-nonylphenol act as agonists for estrogen receptor $\alpha$ in $\mathrm{mcf} 7$ breast cancer cells. Endocrine 22, 275, 2003.

31. ROY D., COLERANGLE J.B., SINGH K.P. Is exposure to environmental or industrial endocrine disrupting estrogenlike chemicals able to cause genomic instability. Front Biosci 3, d913, 1998

32. SOTO A.M., JUSTICIA H., WRAY J.W., SONNENSCHEIN C. P-nonyl-phenol: An estrogenic xenobiotic released from" modified" polystyrene. Environ. Health Perspect. 92, 167, 1991.

33. IN S.J., KIM S.H., GO R.E., HWANG K.A., CHOI K.C. Benzophenone-1 and nonylphenol stimulated mcf-7 breast cancer growth by regulating cell cycle and metastasis-related genes via an estrogen receptor alpha-dependent pathway. J. Toxicol. Environ. Health Part A 78, 492, 2015.

34. YU Z., ZHANG L., WU D. Effects of environmental estrogens on apoptosis induced by estrogen depletion in $\mathrm{t} 47 \mathrm{~d}$ cells. Zhonghua Yu Fang Yi Xue Za Zhi 37, 395, 2003. 
35. MOON H.J., HAN S.Y., SHIN J.-H., KANG I.H., KIM T.S., HONG J.H., KIM S.-H., FENTON S.E. Gestational exposure to nonylphenol causes precocious mammary gland development in female rat offspring. J. Reprod. Dev. 53, 333, 2007.

36. TAIOLI E., BRADLOW H.L., GARBERS S.V., SEPKOVIC D.W., OSBORNE M.P., TRACHMAN J., GANGULY S., GARTE S.J. Role of estradiol metabolism and cypla1 polymorphisms in breast cancer risk. Cancer Detect. Prev. 23, 232, 1999.

37. ACEVEDO R., PARNELL P.G., VILLANUEVA H., CHAPMAN L.M., GIMENEZ T., GRAY S.L., BALDWIN W.S. The contribution of hepatic steroid metabolism to serum estradiol and estriol concentrations in nonylphenol treated mmtvneu mice and its potential effects on breast cancer incidence and latency. J Appl Toxicol 25, 339, 2005.

38. WITTASSEK M., KOCH H.M., ANGERER J., BR NING T. Assessing exposure to phthalates-the human biomonitoring approach. Mol Nutr Food Res 55, 7, 2011.

39. SILVA M.J., BARR D.B., REIDY J.A., MALEK N.A., HODGE C.C., CAUDILL S.P., BROCK J.W., NEEDHAM L.L., CALAFAT A.M. Urinary levels of seven phthalate metabolites in the us population from the national health and nutrition examination survey (nhanes) 1999-2000. Environ. Health Perspect. 112, 331, 2004.

40. HOLMES A.K., KOLLER K.R., KIESZAK S.M., SJODIN A., CALAFAT A.M., SACCO F.D., VARNER D.W., LANIER A.P., RUBIN C.H. Case-control study of breast cancer and exposure to synthetic environmental chemicals among alaska native women. Int J Circumpolar Health 73, 25760, 2014.

41. LÓPEZ-CARRILLO L., HERN NDEZ-RAM REZ R.U., CALAFAT A.M., TORRES-S NCHEZ L., GALV N-PORTILLO M., NEEDHAM L.L., RUIZ-RAMOS R., CEBRI N M.E. Exposure to phthalates and breast cancer risk in northern mexico. Environ. Health Perspect. 118, 539, 2010.

42. KLEINSASSER N.H., KASTENBAUER E.R., WEISSACHER H., MUENZENRIEDER R.K., HARR US U.A. Phthalates demonstrate genotoxicity on human mucosa of the upper aerodigestive tract. Environ. Mol. Mutagen. 35, $9,2000$.

43. SMITH R., LOURIE B. Slow death by rubber duck: How the toxic chemistry of everyday life affects our health. Random House Digital, Inc., Berkeley, 2010.

44. BONEFELD-JORGENSEN E.C., LONG M., BOSSI R., AYOTTE P., ASMUND G., KR GER T., GHISARI M., MULVAD G., KERN P., NZULUMIKI P. Perfluorinated compounds are related to breast cancer risk in greenlandic inuit: A case control study. Environ Health 10, 88, 2011.

45. GIESY J.P., KANNAN K. Global distribution of perfluorooctane sulfonate in wildlife. Environ. Sci. Technol. 35, 1339, 2001.

46. BENNINGHOFF A.D., BISSON W.H., KOCH D.C., EHRESMAN D.J., KOLLURI S.K., WILLIAMS D.E. Estrogen-like activity of perfluoroalkyl acids in vivo and interaction with human and rainbow trout estrogen receptors in vitro. Toxicol. Sci. 120, 42, 2011.

47. SONTHITHAI P., SURIYO T., THIANTANAWAT A., WATCHARASIT P., RUCHIRAWAT M., SATAYAVIVAD J. Perfluorinated chemicals, pfos and pfoa, enhance the estrogenic effects of 17 beta-estradiol in $47 \mathrm{~d}$ human breast cancer cells. J Appl Toxicol 2015.

48. GHISARI M., EIBERG H., LONG M., BONEFELDJORGENSEN E.C. Polymorphisms in phase $i$ and phase ii genes and breast cancer risk and relations to persistent organic pollutant exposure: A case-control study in inuit women. Environ Health 13, 19, 2014.

49. GRICE M.M., ALEXANDER B.H., HOFFBECK R., KAMPA D.M. Self-reported medical conditions in perfluorooctanesulfonyl fluoride manufacturing workers. J. Occup. Environ. Med. 49, 722, 2007.

50. LYCHE J.L., ROSSELAND C., BERGE G., POLDER A. Human health risk associated with brominated flameretardants (bfrs). Environ Int 74, 170, 2015.

51. NI H.G., DING C., LU S.Y., YIN X.L., SAMUEL S.O. Food as a main route of adult exposure to pbdes in shenzhen, china. Sci. Total Environ. 437, 10, 2012.

52. LORBER M. Exposure of americans to polybrominated diphenyl ethers. J Expo Sci Environ Epidemiol 18, 2, 2008.

53. DARNERUD P.O. Brominated flame retardants as possible endocrine disrupters. Int. J. Androl. 31, 152, 2008.

54. MCDONALD T.A. A perspective on the potential health risks of pbdes. Chemosphere 46, 745, 2002.

55. LI Z.H., LIU X.Y., WANG N., CHEN J.S., CHEN Y.H., HUANG J.T., SU C.H., XIE F., YU B., CHEN D.J. Effects of decabrominated diphenyl ether (pbde-209) in regulation of growth and apoptosis of breast, ovarian, and cervical cancer cells. Environ. Health Perspect. 120, 541, 2012.

56. HURLEY S., REYNOLDS P., GOLDBERG D., NELSON D.O., JEFFREY S.S., PETREAS M. Adipose levels of polybrominated diphenyl ethers and risk of breast cancer. Breast Cancer Res. Treat. 129, 505, 2011.

57. SJÖDIN A., WONG L.-Y., JONES R.S., PARK A., ZHANG Y., HODGE C., DIPIETRO E., MCCLURE C., TURNER W., NEEDHAM L.L. Serum concentrations of polybrominated diphenyl ethers (pbdes) and polybrominated biphenyl (pbb) in the united states population: 2003-2004. Environ. Sci. Technol. 42, 1377, 2008.

58. MCELROY J.A., KANAREK M.S., TRENTHAM-DIETZ A., ROBERT S.A., HAMPTON J.M., NEWCOMB P.A., ANDERSON H.A., REMINGTON P.L. Potential exposure to pcbs, ddt, and pbdes from sport-caught fish consumption in relation to breast cancer risk in wisconsin. Environ. Health Perspect. 112, 156, 2004.

59. DANJOU A.M.N., FERVERS B., BOUTRON-RUAULT M.C., PHILIP T., CLAVEL-CHAPELON F., DOSSUS L. Estimated dietary dioxin exposure and breast cancer risk among women from the french e3n prospective cohort. Breast Cancer Res. 17, 2015.

60. MANUWALD U., GARRIDO M.V., BERGER J., MANZ A., BAUR X. Mortality study of chemical workers exposed to dioxins: Follow-up 23 years after chemical plant closure. Occup Environ Med 69, 636, 2012.

61. CHAN M.Y., HUANG H., LEUNG L.K. 2,3,7,8-tetrachlorodibenzo-para-dioxin increases aromatase (cyp19) mrna stability in mcf-7 cells. Mol. Cell. Endocrinol. 317, 8, 2010.

62. REVICH B., AKSEL E., USHAKOVA T., IVANOVA I., ZHUCHENKO N., KLYUEV N., BRODSKY B., SOTSKOV Y. Dioxin exposure and public health in chapaevsk, russia. Chemosphere 43, 951, 2001.

63. PETREAS M., SMITH D., HURLEY S., JEFFREY S.S., GILLISS D., REYNOLDS P. Distribution of persistent, lipid-soluble chemicals in breast and abdominal adipose tissues: Lessons learned from a breast cancer study. Cancer Epidemiol. Biomarkers Prev. 13, 416, 2004.

64. STEENLAND K., BERTAZZI P., BACCARELLI A., KOGEVINAS M. Dioxin revisited: Developments since the 1997 iarc classification of dioxin as a human carcinogen. Environ. Health Perspect. 112, 1265, 2004. 
65. NEBERT D.W., DALTON T.P., OKEY A.B., GONZALEZ F.J. Role of aryl hydrocarbon receptor-mediated induction of the cyp1 enzymes in environmental toxicity and cancer. J. Biol. Chem. 279, $23847,2004$.

66. SHI Z.Q., DRAGIN N., MILLER M.L., STRINGER K.F., JOHANSSON E., CHEN J., UNO S., GONZALEZ F.J., RUBIO C.A., NEBERT D.W. Oral benzo[a]pyrene-induced cancer: Two distinct types in different target organs depend on the mouse cyp1 genotype. Int. J. Cancer 127, 2334, 2010.

67. LEW B.J., COLLINS L.L., O'REILLY M.A., LAWRENCE B.P. Activation of the aryl hydrocarbon receptor during different critical windows in pregnancy alters mammary epithelial cell proliferation and differentiation. Toxicol. Sci. 111, 151, 2009.

68. WANG S.L., CHANG Y.C., CHAO H.R., LI C.M., LI L.A., LIN L.Y., PAPKE O. Body burdens of polychlorinated dibenzo-p-dioxins, dibenzofurans, and biphenyls and their relations to estrogen metabolism in pregnant women. Environ. Health Perspect. 114, 740, 2006.

69. CASTRO-RIVERA E., WORMKE M., SAFE S. Estrogen and aryl hydrocarbon responsiveness of ecc-1 endometrial cancer cells. Mol. Cell. Endocrinol. 150, 11, 1999.

70. PEARCE S.T., LIU H., RADHAKRISHNAN I., ABDELRAHIM M., SAFE S., JORDAN V.C. Interaction of the aryl hydrocarbon receptor ligand 6-methyl-1,3,8trichlorodibenzofuran with estrogen receptor alpha. Cancer Res. 64, 2889, 2004.

71. BOVERHOF D.R., KWEKEL J.C., HUMES D.G., BURGOON L.D., ZACHAREWSKI T.R. Dioxin induces an estrogen-like, estrogen receptor-dependent gene expression response in the murine uterus. Mol. Pharmacol. 69, 1599, 2006.

72. GJERNES M.H., SCHLENK D., ARUKWE A. Estrogen receptor-hijacking by dioxin-like 3,3' 4,4',5pentachlorobiphenyl (pcb126) in salmon hepatocytes involves both receptor activation and receptor protein stability. Aquat. Toxicol. 124, 197, 2012.

73. SPINK B.C., BENNETT J.A., LOSTRITTO N., COLE J.R., SPINK D.C. Expression of the aryl hydrocarbon receptor is not required for the proliferation, migration, invasion, or estrogen-dependent tumorigenesis of mcf-7 breast cancer cells. Mol. Carcinog. 52, 544, 2013.

74. BRUNNBERG S., ANDERSSON P., POELLINGER L., HANBERG A. The constitutively active ah receptor (caahr) mouse as a model for dioxin exposure - effects in reproductive organs. Chemosphere 85, 1701, 2011.

75. MADAK-ERDOGAN Z., KATZENELLENBOGEN B.S. Aryl hydrocarbon receptor modulation of estrogen receptor alpha-mediated gene regulation by a multimeric chromatin complex involving the two receptors and the coregulator rip140. Toxicol. Sci. 125, 401, 2012.

76. FLESCH-JANYS D. Analyses of exposure to polychlorinated dibenzo-p-dioxins, furans, and hexachlorocyclohexane and different health outcomes in a cohort of former herbicideproducing workers in hamburg, germany. Teratog., Carcinog. Mutagen. 17, 257, 1997.

77. WARNER M., ESKENAZI B., MOCARELLI P., GERTHOUX P.M., SAMUELS S., NEEDHAM L., PATTERSON D., BRAMBILLA P. Serum dioxin concentrations and breast cancer risk in the seveso women's health study. Environ. Health Perspect. 110, 625, 2002.

78. PESATORI A.C., CONSONNI D., RUBAGOTTI M., GRILLO P., BERTAZZI P.A. Cancer incidence in the population exposed to dioxin after the "seveso accident": Twenty years of follow-up. Environ Health 8, 2009.

79. DAI D., OYANA T.J. Spatial variations in the incidence of breast cancer and potential risks associated with soil dioxin contamination in midland, saginaw, and bay counties, michigan, USA. Environ Health 7, 2008.

80. BIDGOLI S.A., EFTEKHARI T., SADEGHIPOUR R. Role of xenoestrogens and endogenous sources of estrogens on the occurrence of premenopausal breast cancer in iran. Asian Pac. J. Cancer Prev. 12, 2425, 2011.

81. VIEL J.F., CLEMENT M.C., HAGI M., GRANDJEAN S., CHALLIER B., DANZON A. Dioxin emissions from a municipal solid waste incinerator and risk of invasive breast cancer: A population-based case-control study with gisderived exposure. Int J Health Geogr 7, 2008.

82. SHE J., HOLDEN A., SHARP M., TANNER M., WILLIAMS-DERRY C., HOOPER K. Polybrominated diphenyl ethers (pbdes) and polychlorinated biphenyls (pcbs) in breast milk from the pacific northwest. Chemosphere 67, S307, 2007.

83. THOMPSON M.R., BOEKELHEIDE K. Multiple environmental chemical exposures to lead, mercury and polychlorinated biphenyls among childbearing-aged women (nhanes 1999-2004): Body burden and risk factors. Environ. Res. 121, 23, 2013.

84. WOLFF M.S., BERKOWITZ G.S., BROWER S., SENIE R., BLEIWEISS I.J., TARTTER P., PACE B., ROY N., WALLENSTEIN S., WESTON A. Organochlorine exposures and breast cancer risk in new york city women. Environ. Res. 84, 151, 2000.

85. KEY T., REEVES G. Organochlorines in the environment and breast cancer. BMJ 308, 1520, 1994.

86. ADAMI H.O., LIPWORTH L., TITUS-ERNSTOFF L., HSIEH C.C., HANBERG A., AHLBORG U., BARON J., TRICHOPOULOS D. Organochlorine compounds and estrogen-related cancers in women. Cancer Causes Control 6, 551, 1995.

87. GOLDEN R., DOULL J., WADDELL W., MANDEL J. Potential human cancer risks from exposure to pcbs: A tale of two evaluations. Crit. Rev. Toxicol. 33, 543, 2003.

88. BOSETTI C., NEGRI E., FATTORE E., LA VECCHIA C. Occupational exposure to polychlorinated biphenyls and cancer risk. Eur. J. Cancer Prev. 12, 251, 2003.

89. BRODY J.G., MOYSICH K.B., HUMBLET O., ATTFIELD K.R., BEEHLER G.P., RUDEL R.A. Environmental pollutants and breast cancer - epidemiologic studies. Cancer 109, 2667, 2007.

90. WOOLCOTT C.G., ARONSON K.J., HANNA W.M., SENGUPTA S.K., MCCREADY D.R., STERNS E.E., MILLER A.B. Organochlorines and breast cancer risk by receptor status, tumor size, and grade (canada). Cancer Causes Control 12, 395, 2001.

91. DEMERS A., AYOTTE P., BRISSON J., DODIN S., ROBERT J., DEWAILLY É. Plasma concentrations of polychlorinated biphenyls and the risk of breast cancer: A congener-specific analysis. Am. J. Epidemiol. 155, 629, 2002.

92. DIORIO C., DUMAS I., SANDANGER T.M., AYOTTE P. Levels of circulating polychlorinated biphenyls and mammographic breast density. Anticancer Res. 33, 5483, 2013.

93. FENTON S.E. Endocrine-disrupting compounds and mammary gland development: Early exposure and later life consequences. Endocrinology 147, s18, 2006.

94. COHN B.A., TERRY M.B., PLUMB M., CIRILLO P.M. Exposure to polychlorinated biphenyl (pcb) congeners measured shortly after giving birth and subsequent risk of maternal breast cancer before age 50. Breast Cancer Res. Treat. 136, 267, 2012. 
95. GOLDEN R., KIMBROUGH R. Weight of evidence evaluation of potential human cancer risks from exposure to polychlorinated biphenyls: An update based on studies published since 2003. Crit. Rev. Toxicol. 39, 299, 2009.
96. SILVER S.R., WHELAN E.A., DEDDENS J.A., STEENLAND N.K., HOPF N.B., WATERS M.A., RUDER A.M., PRINCE M.M., YONG L.C., HEIN M.J. Occupational exposure to polychlorinated biphenyls and risk of breast cancer. Environ. Health Perspect. 117, 276, 2009. 